\title{
Analisis Hukum Pertanggungjawaban Pidana Apoteker dalam Malapraktik Kefarmasian
}

\section{Legal Analysis of Pharmacists' Criminal Liability in Pharmaceutical Practices}

\author{
Ahmad Arif \\ Universitas Halu Oleo \\ E-mail:arifa9205@gmail.com \\ Herman \\ Pascasarjana Universitas Halu Oleo \\ E-mail: hermanmurhum2009@gmail.com \\ Oheo K. Haris \\ Pascasarjana Universitas Halu Oleo \\ E-mail:oheokh@gmail.com
}

\begin{abstract}
This study aims to: 1 . To determine the pharmacist's criminal liability in pharmaceutical malpractice. 2. To find out the legal protection of pharmacist malpractice victims.

This type of research is legal research. The approach to the problem in this study was carried out in 2 (two) approaches, namely the legislation approach (statue approach), legal concept analysis approach (analytical and conceptual approach and case approach). In this study, the sources of legal material were used sourced from 2 (two) sources of legal material, namely primary legal material and secondary legal material.

This study shows that: 1. criminal liability, a pharmacist must be clearly stated as the creator of a crime (malpractice) first. The criminal responsibility to the pharmacist is asked or not, is the second issue, depending on the policy of the parties concerned to decide whether it is deemed necessary or not to prosecute the criminal responsibility. A pharmacist is considered capable of being responsible if the pharmacist is aware of the actual actions he did and the consequences of the results of his actions. An action can be categorized as a pharmacist's malpractice if it fulfills the criminal offense formula, that is, the act must be a disgraceful act and wrong attitude is carried out in the form of carelessness or negligence/negligence. 2. Legal protection against pharmacist malpractice victims can be done theoretically by nonjuridical and juridical methods in the form of preventive measures. Protection of victims of crime is given depending on the type of suffering/loss suffered by the victim.
\end{abstract}


The basis of the protection of victims of crime can be seen from several theories, such as utility theory, responsibility theory and compensation theory.

Keyword: criminal liability; pharmacists; pharmaceutical malpractice

Abstrak: Penelitian ini bertujuan untuk: 1. Untuk mengetahui pertanggungjawaban pidana apoteker dalam malapraktik kefarmasian. 2. Untuk mengetahui perlindungan hukum terhadap korban malapraktik apoteker.

Tipe penelitian ini adalah penelitian hukum (legal research). Pendekatan terhadap permasalahan dalam penelitian ini dilakukan dengan 2 (dua) cara pendekatan, yaitu pendekatan perundang-undangan (statue approach), pendekatan analisis konsep hukum (analytical and conceptual approach) dan pendekatan kasus (case approach). Dalam penelitian ini, sumber bahan hukum yang dipergunakan bersumber dari 2 (dua) sumber bahan hukum yaitu bahan hukum primer dan bahan hukum sekunder.

Penelitian ini menunjukkan bahwa: 1. pertanggungjawaban pidana, seorang apoteker harus jelas terlebih dahulu dinyatakan sebagai pembuat suatu tindak pidana (malapraktik). Pertanggungjawaban pidana kepada apoteker itu diminta atau tidak, adalah persoalan kedua, tergantung kebijakan pihak yang berkepentingan untuk memutuskan apakah dirasa perlu atau tidak untuk menuntut pertanggungjawaban pidana tersebut. Seorang apoteker dianggap mampu bertanggung jawab apabila apoteker tersebut menyadari akan tindakan yang sebenarnya dilakukannya dan akibat dari hasil perbuatannya tersebut. Suatu perbuatan dapat dikategorikan sebagai pharmacists malpractice apabila memenuhi rumusan delik pidana, yaitu perbuatan tersebut harus merupakan perbuatan tercela dan dilakukan sikap batin yang salah yaitu berupa kecerobohan atau kealpaan/kelalaian. 2.Perlindungan hukum terhadap korban malapraktik apoteker secara teoritis dapat dilakukan dengan cara non-yuridis dan yuridis dalam bentuk tindakan-tindakan pencegahan. Perlindungan terhadap korban kejahatan diberikan tergantung pada jenis penderitaan/kerugian yang diderita oleh korban. Dasar dari perlindungan korban kejahatan dapat dilihat dari beberapa teori, seperti teori utilitas, teori tanggung jawab dan teori ganti rugi.

Kata kunci: pertanggungjawaban pidana; apoteker; malapraktik kefarmasian

\section{PENDAHULUAN}

Masalah kesehatan merupakan keprihatinan serius di setiap negara, baik negara maju maupun negara yang sedang berkembang seperti Indonesia. karena kesehatan merupakan salah satu faktor yang menentukan kemajuan suatu negara dan merupakan hak asasi manusia. Negara memiliki kewajiban kepada rakyatnya untuk menyediakan layanan kesehatan dan menetapkan aturan-aturan hukum yang terkait dengan kepentingan perlindungan kesehatan.

Kesehatan merupakan hal terpenting yang diperlukan oleh tubuh manusia. Hal ini sejalan dengan pengertian kesehatan yang diberikan oleh dunia internasional sebagai: 
A state of complete physical, mental, and social, well being and not merely the absence of desease or infirmity ${ }^{1}$

Berdasarkan Undang-Undang Nomor 36 Tahun 2009 Tentang Kesehatan ditegaskan bahwa pembangunan kesehatan pada dasarnya menyangkut semua segi kehidupan, baik fisik, mental maupun sosial ekonomi. Perkembangan pembangunan kesehatan selama ini, telah terjadi perubahan orientasi baik tata nilai maupun pemikiran terutama mengenai upaya pemecahan masalah dibidang kesehatan yang dipengaruhi oleh politik, ekonomi, sosial budaya, pertahanan keamanan serta ilmu pengetahuan dan teknologi. Perubahan orientasi tersebut akan mempengaruhi proses penyelenggaraan pembangunan kesehatan.

Hukum kedokteran dan hukum kesehatan mulai di perkenalkan di Indonesia dengan terbentuknya kelompok studi untuk Hukum Kedokteran di Universitas Indonesia pada tanggal 1 November 1982 di Rumah Sakit Cipto Mangunkusumo oleh beberapa dokter dan sarjana hukum. ${ }^{2}$

Apoteker adalah suatu profesi yang berhubungan dengan seni dan ilmu dalam penyediaan bahan sumber alam dan bahan sintetis yang cocok dan menyenangkan untuk didistribusikan dan digunakan dalam pengobatan dan pencegahan suatu penyakit. ${ }^{3}$ Dalam pelayanan kesehatan, obat merupakan komponen yang penting karena diperlukan dalam sebagian besar upaya kesehatan. Dewasa ini meningkatnya kesadaran dan pengetahuan masyarakat tentang kesehatan juga mendorong masyarakat menuntut pelayanan kesehatan termasuk pelayanan obat yang semakin berkualitas dan profesional. ${ }^{4}$

Pesatnya perkembangan ilmu kefarmasian maka apoteker dikenal pula dengan sebutan farmasis, telah dapat menempati bidang pekerjaan yang makin luas meliputi apotek, rumah sakit, lembaga pemerintahan, perguruan tinggi, lembaga penelitian, laboratorium pengujian, laboratorium klinis, laboratorium forensik, berbagai jenis industri, meliputi industri obat, kosmetik, jamu, obat herbal dan industri vaksin, lembaga informasi obat serta badan asuransi kesehatan adalah tempat-tempat untuk farmasis melaksanakan pengabdian profesi farmasis.

\footnotetext{
Bahder Nasution, Sistem Hukum, Jakarta: PT. Rineka Cipta, 2005, hlm. 1

Amri Amir, Bunga Ranpai Hukum Kesehatan, Jakarta: Widya Medika,1997 hlm. 2.

Barda Nawawi Arief, Bunga Rampai Kebijakan Hukum Pidana, Jakarta: Kencana, 2008, hlm. 42.

Purwanto Hardjosaputra, Daftar Obat Indonesia Edisi II, Jakarta: PT. Mulia Purna Jaya Terbit, 2008. hlm. 5.
} 
Menyadari pentingnya peranan seorang Apoteker yang profesional yang memiliki landasan praktik profesi yaitu ilmu kefarmasian, hukum dan etika profesi yang mutlak dibutuhkan dalam usaha untuk meningkatkan upaya kesehatan di tengah masyarakat, maka sebagai seorang Apoteker harus memiliki bekal ilmu pengetahuan, dan keterampilan yang cukup di bidang kefarmasian baik dalam teori maupun praktik. Dalam pengabdian profesinya seorang apoteker harus berpedoman pada satu ikatan moral yaitu kode etik apoteker terdiri dari kewajiban umum, kewajiban terhadap masyarakat, kewajiban terhadap apoteker lain(sejawat) dan terhadap tenaga kesehatan lain.

Tenaga kesehatan (Apoteker) sering menjadi perhatian masyarakat karena sifat pengabdiannya kepada masyarakat sangat dibutuhkan. Etika profesi yang semula mampu menjaganya citra profesi kesehatan semakin melemah, sehingga Pemerintah membuat beberapa peraturan perundang-undangan yang mengatur praktik profesi kesehatan dan lebih memberdayakan pasien sebagai pengguna pelayanan kesehatan. Di bidang kefarmasian pemerintah telah membuat peraturan perundangan yang menyangkut bidang kefarmasian seperti Undang-Undang Nomor 36 Tahun 2009 Tentang Kesehatan, UndangUndang Nomor 36 Tahun 2014 Tentang Tenaga Kesehatan, dan Peraturan Pemerintah 51 Tahun 2009 Tentang Pekerjaan Kefarmasian,

Salah satu kejahatan dalam hukum kesehatan yang marak terjadi pada saat ini adalah kejahatan dibidang farmasi. Meskipun telah ada peraturan perundanganperundangan di bidang kefarmasian, tidak jarang ditemui apoteker melakukan tindakan malapraktik yang menyebabkan kerugian atau meninggalnya seseorang. Hal ini tentunya bisa masuk dalam ranah pidana apabila memang ditemukan adanya unsur kelalaian atau kesengajaan yang mengakibatkan kerugian luka berat atau meninggalnya seseorang dalam tindakan apoteker tersebut.

\section{METODE PENELITIAN}

Tipe penelitian yang penulis gunakan dalam penelitian ini adalah penelitian hukum (legal research). Pendekatan terhadap permasalahan dalam penelitian ini dilakukan dengan 2 (dua) cara pendekatan, yaitu pendekatan perundang-undangan (statue approach), pendekatan analisis konsep hukum (analytical and conceptual approach) dan pendekatan kasus (case approach). Teknik pengumpulan bahan hukum yang mendukung dan berkaitan dengan pemaparan penelitian ini adalah studi dokumen (studi kepustakaan), 
yang dilakukan dengan cara meneliti bahan-bahan pustaka atau data sekunder yang terdiri dari bahan hukum primer, bahan hukum sekunder dan bahan hukum tertier.

\section{ANALISIS DAN PEMBAHASAN}

\section{Pertanggungjawaban Pidana Apoteker dalam Malapraktik Kefarmasian}

Setiap upaya kesehatan tidak selalu dapat memberikan kepuasan kepada pasien dengan baik, bisa jadi menimbulkan kecacatan atau bahkan kematian. Malapetaka seperti ini tidak mungkin dapat dihindari sama sekali, sehingga menimbulkan permasalahan hukum jika pasien akan menuntut pemberi pelayanan, yang perlu dikaji apakah malapetaka tersebut merupakan malapraktik atau risiko dari tindakan yang diberikan oleh apoteker dalam pelayanan kefarmasian. Demikian juga permasalahan hukum yang terjadi untuk kalangan kesehatan perlu pemahaman oleh para penegak hukum termasuk pengadilan dalam memberikan putusan timbulnya dugaan malapraktik. Karena pada umumnya tuntutan pasien berdasarkan akibat yang terjadi atau hasil yang menimpa pada dirinya, sedangkan dugaan malapraktik kesehatan dalam pelayanan kefarmasian sangat diperlukan causa atau penyebabnya yang menyebabkan terjadinya tuntutan oleh pasien.

Setiap tenaga kesehatan dalam memberikan putusan atas suatu tindakan medis harus dilandasi atas kesadaran, tanggung jawab dan moral yang tinggi sesuai dengan etika profesi masing-masing. Salah satu tenaga kesehatan yang memiliki kewenangan dalam memberikan obat kepada pasien adalah apoteker. Apoteker adalah seseorang yang mempunyai keahlian dan kewenangan di bidang kefarmasian, baik di apotek, rumah sakit, industri, pendidikan, dan bidang lain yang masih berkaitan dengan bidang kefarmasian. Apoteker juga merupakan tenaga kesehatan sarjana. Apoteker merupakan bagian dari tenaga kesehatan sebagai tenaga kefarmasian. Hubungan dokter dengan tenaga kesehatan lainnya termasuk apoteker memiliki posisi yang dominan. Pasien pada umumnya cenderung bersikap pasif. Pasal 11 Undang-Undang Nomor 36 Tahun 2014 Tentang Tenaga Kesehatan diatur mengenai fungsi dan tugas apoteker.

Praktik apoteker bukanlah pekerjaan yang dapat dilakukan oleh siapa saja, melainkan hanya boleh dilakukan oleh kelompok profesional apoteker tertentu yang berkompetensi dan memenuhi standar tertentu dan telah mendapat izin dari institusi yang berwenang, serta bekerja sesuai dengan standar dan profesionalisme yang diterapkan oleh organisasi profesi. 
Pelayanan kesehatan yang diberikan seorang tenaga medis kepada pasien merupakan tindakan profesi tenaga medis. Tindakan medis merupakan suatu tindakan yang penuh dengan risiko. Risiko tersebut dapat terjadi disebabkan oleh sesuatu yang tidak dapat diprediksikan sebelumnya atau risiko yang terjadi akibat tindakan medis yang salah. Dikatakan tindakan salah apabila tenaga medis tidak melakukan pekerjaannya sesuai dengan standar profesi medik dan prosedur tindakan medik. Apabila seorang tenaga medis melakukan tindakan salah, maka tenaga medis tersebut dapat dikategorikan melakukan tindakan malapraktik, sehingga dapat menyangkut aspek hukum pidana.

Dalam menjaga kesehatan tentu sering kali ditemukan beberapa tindakan-tindakan yang mengancam kesehatan tersebut dapat berupa kesengajaan, kelalaian, ataupun kecelakaan. Hal-hal seperti ini dapat dikategorikan sebagai malapraktik yang lebih ditekankan kepada tindak pidana malapraktik. Di dalam Undang-Undang Kesehatan tidak dicantumkan pengertian tentang Malapraktik, namun di dalam Ketentuan Pidana pada Bab XX diatur di dalam Pasal 190 dinyatakan bahwa:

(1) Pimpinan fasilitas pelayanan kesehatan dan/atau tenaga kesehatan yang melakukan praktik atau pekerjaan pada fasilitas pelayanan kesehatan yang dengan sengaja tidak memberikan pertolongan pertama terhadap pasien dalam keadaan gawat darurat sebagaimana dimaksud dalam Pasal 32 ayat (2) atau Pasal 85 ayat (2) dipidana dengan pidana penjara paling lama 2 (dua) tahun dan denda paling banyak Rp.200.000.000 (dua ratus juta rupiah).

(2) Dalam hal perbuatan sebagaimana dimaksud pada ayat (1) mengakibatkan terjadinya kecacatan atau kematian, pimpinan fasilitas pelayanan kesehatan dan/atau tenaga kesehatan tersebut dipidana dengan pidana penjara paling lama 10 (sepuluh) tahun dan denda paling banyak satu miliar rupiah.

Pada Pasal 63 Undang-Undang Nomor 36 Tahun 2009 Tentang Kesehatan jelas diatur mengenai upaya penyembuhan penyakit dan upaya untuk pemulihan kesehatan sebagai tolak ukur perbuatan malapraktik menurut ketentuan pidana yang terdapat pada pasal 190 di atas. Pasal 63 Undang-Undang Nomor 36 Tahun 2009 Tentang Kesehatan menyatakan bahwa:

(1) Penyembuhan penyakit dan pemulihan kesehatan diselenggarakan untuk mengembalikan status kesehatan akibat penyakit, mengembalikan fungsi badan akibat cacat atau menghilangkan cacat. (2) Penyembuhan penyakit dan pemulihan kesehatan dilakukan dengan pengobatan dan atau perawatan. 
(2) Pengobatan dan atau perawatan dapat dilakukan berdasarkan ilmu kedokteran dan ilmu keperawatan atau cara lain yang dapat dipertanggungjawabkan.

(3) Pelaksanaan pengobatan dan atau perawatan berdasarkan ilmu kedokteran atau ilmu keperawatan hanya dapat dilakukan oleh tenaga kesehatan yang mempunyai keahlian dan kewenangan untuk itu.

(4) Pemerintah melakukan pembinaan dan pengawasan terhadap pelaksanaan pengobatan dan atau perawatan berdasarkan cara lain yang dapat dipertanggungjawabkan.

Pembentukan perundang-undangan di bidang pelayanan kesehatan diperlukan, hal ini dilakukan supaya tindak pidana malapraktik dapat dijerat dengan ketentuan yang tegas.

Beberapa contoh kesalahan dalam pelayanan kefarmasian yang perlu pengkajian apakah dapat dikatakan malapraktik atau tidak, beberapa kesalahan dalam pengkajian resep:

a. Apoteker menerima resep obat tapi tidak melakukan skrining/pengkajian

b. Apoteker menerima resep dokter akan tetapi tulisannya meragukan/tidak jelas., tapi apoteker tidak melakukan kewajibannya untuk konfirmasi dulu kepada dokter penulis resep

c. Salah menginterpretasi atau membaca resep, sehingga obat yang diberikan tidak sesuai dengan peresepan dokter.

Kesalahan tersebut di atas dapat menimbulkan dampak negatif (kerugian, cacat, meninggal) pada pasien dan secara umum kesalahan dibedakan dalam 2 (dua) bagian pertama dampak kerugian karena risiko dari obatnya yang disebut cedera akibat obat. kedua dampak yang merugikan pasien karena kesalahan manusianya (apoteker) yang lebih dikenal dengan medication error. Dengan melihat pengertian-pengertian di atas maka dapat disimpulkan bahwa ada atau tidaknya malapraktik bukanlah ditentukan atas dasar „hasil akhirnya" melainkan atas dasar "prosesnya".

Adanya perbedaan penting antaran tindak pidana biasa dengan tindak pidana medik adalah ${ }^{5}$ :

a. Pada tindak pidana biasa yang terutama diperhatikan adalah akibatnya (gevolg) sedang pada tindak pidana medik yang penting bukan akibatnya tetapi

$5 \quad$ Ibid, hlm. 90 
penyebabnya/kausanya. Walaupun akibatnya fatal, tetapi tidak ada unsur kesalahan/kelalaian maka tindakan tersebut tidak dapat disalahkan.

b. Tindak pidana biasanya dapat ditarik garis langsung antara sebab dan akibatnya karena kasusnya jelas, orang menusuk perut orang lain dengan pisau hingga perutnya terluka. Pada setiap tindakan medis, seperti pembedahan, akan selalu ada risiko timbulnya sesuatu yang bersifat negatif, diperlukan persetujuan atau informed consent dari pasien.

Apoteker yang dianggap telah melakukan kelalaian sehingga menimbulkan persangkaan malapraktik oleh pasien merupakan pihak yang bertanggung jawab atas tindakannya. Seseorang yang dianggap mampu bertanggung jawab apabila orang tersebut menyadari akan tindakan yang sebenarnya dilakukannya dan akibat dari hasil perbuatannya tersebut. Suatu perbuatan dapat dikategorikan sebagai pharmacists malpractice apabila memenuhi rumusan delik pidana, yaitu perbuatan tersebut harus merupakan perbuatan tercela dan dilakukan sikap batin yang salah yaitu berupa kecerobohan atau kealpaan/kelalaian.

Untuk dapat dipidananya seorang apoteker maka tindakan malapraktik yang dilakukannya harus ada unsur6:

a. Melakukan perbuatan pidana;

b. Mampu bertanggung jawab;

c. Dengan sengaja atau kealpaan; dan

d. Tidak ada alasan pemaaf.

Dalam rangka penegakan hukum law enforcement terdapat kehendak agar hukum tegak, sehingga nilai-nilai yang diperjuangkan melalui instrumen hukum yang bersangkutan dapat diwujudkan. ${ }^{7}$ Untuk adanya pertanggungjawaban pidana, seorang apoteker harus jelas terlebih dahulu dinyatakan sebagai pembuat suatu tindak pidana. Pertanggungjawaban itu diminta atau tidak, adalah persoalan kedua, tergantung kebijakan pihak yang berkepentingan untuk memutuskan apakah dirasa perlu atau tidak untuk menuntut pertanggungjawaban tersebut. Masalah ini menyangkut subjek tindak pidana (apoteker) yang umumnya telah dirumuskan oleh pembuat undang-undang.

6 Roeslan Saleh, Perbuatan Pidana dan Pertanggungjawaban Pidana, Dua Pengertian Dasar dalam Hukum Pidana, Jakarta: Centra, 1998. hlm. 79

7 Oheo K. Haris, Telaah Yuridis Penerapan Sanksi Di Bawah Minimum Khusus Pada Perkara Pidana Khusus, Jurnal Ius Constituendum, Volume 2 Nomor 2 Tahun 2017, http://journals.usm.ac.id/index.php/jic/article/view/663 diakses pada tanggal 28 Juni 2019, hlm. 241. 
Menurut Roeslan Saleh pertanggungjawaban pidana diartikan sebagai diteruskannya celaan yang objektif yang ada pada perbuatan pidana dan secara subjektif memenuhi syarat untuk dapat dipidana karena perbuatannya itu. ${ }^{8}$ Apa yang dimaksud dengan celaan objektif adalah perbuatan yang dilakukan oleh seseorang tersebut merupakan perbuatan yang dilarang, perbuatan dilarang yang dimaksud di sini adalah perbuatan yang memang bertentangan atau dilarang oleh hukum baik hukum formil maupun hukum materil. Sedangkan yang dimaksud dengan celaan subjektif merujuk kepada si pembuat perbuatan terlarang tersebut, atau dapat dikatakan celaan yang subjektif adalah orang yang melakukan perbuatan yang dilarang atau bertentangan dengan hukum.

\section{Perlindungan Hukum Terhadap Korban Malapraktik Apoteker}

Perlindungan hukum merupakan hal terpenting dalam suatu negara hukum, karena perlindungan hukum merupakan hak setiap warga negara dan kewajiban dari negara sebagai penyelenggara perlindungan.

Philipus M. Hadjon berpendapat bahwa Perlindungan Hukum adalah perlindungan akan harkat dan martabat, serta pengakuan terhadap hak-hak asasi manusia yang dimiliki oleh subyek hukum berdasarkan ketentuan hukum dari kesewenangan. ${ }^{9}$ Sedangkan menurut Setiono, perlindungan hukum adalah tindakan atau upaya untuk melindungi masyarakat dari perbuatan sewenang-wenang oleh penguasa yang tidak sesuai dengan aturan hukum, untuk mewujudkan ketertiban dan ketenteraman sehingga memungkinkan manusia untuk menikmati martabatnya sebagai manusia. ${ }^{10}$

Perlunya diberikan perlindungan hukum pada korban kejahatan secara memadai tidak saja merupakan isu nasional, tetapi juga internasional, Oleh karena itu, masalah ini perlu memperoleh perhatian yang serius. ${ }^{11}$ Pentingnya perlindungan korban kejahatan memperoleh perhatian serius, dapat dilihat dari dibentuknya Declaration of Basic Principles of Justice for Victims of Crime and Abuses of Power oleh Perserikatan BangsaBangsa (PBB), sebagai hasil dari The Seventh United Nation Conggres on the Prevention of

8 Roeslan Saleh, Pikiran-Pikiran Tentang Pertanggung Jawaban Pidana, Cetakan Pertama, Jakarta: Ghalia Indonesia, 1982, hlm. 33.

9 Philipus M. Hadjon, Perlindungan Bagi Rakyat di Indonesia, Surabaya: PT.Bina Ilmu,1987, hlm. 1-2.

10 Setiono, Rule of Law (Supremasi Hukum), Surakarta; Magister Ilmu Hukum Program Pascasarjana Universitas Sebelas Maret, 2004. hlm. 3.

11 Dikdik M. Arief Mansur, Elisatris Gultom, Urgensi Perlindungan Korban Kejahatan Antara Norma dan Realita, Jakarta: PT Raja Grafindo Persada, 2007, hlm. 23 
Crime and the Treatment of Offenders, yang berlangsung di Milan, Italia, September 1985, dalam salah satu rekomendasinya disebutkan: “Offenders or third parties responsible for their behaviour should, where appropriate, make fair restitution to victims, their families or dependents. Such restitution should include the return of property or payment for the harm or loss suffered, reimbursement of expenses incurred as a result of the victimization, the provision of services and the restoration of rights". (Pelaku atau mereka yang bertanggungjawab atas suatu perbuatan melawan hukum, harus memberi restitusi kepada korban, keluarga atau wali korban. Restitusi tersebut berupa pengembalian hak milik atau mengganti kerugian yang diderita korban, kerugian biaya atas kelalaian yang telah dilakukannya sehingga menimbulkan korban, yang merupakan suatu penetapan UndangUndang sebagai bentuk pelayanan dan pemenuhan atas hak).

Konsep perlindungan korban kejahatan adalah suatu peristiwa kejahatan tentunya pelaku dan korbanlah yang menjadi tokoh utamanya yang sangat berperan. Pengertian perlindungan korban dapat dilihat dari dua makna yaitu ${ }^{12}$ :

a. Perlindungan hukum untuk tidak menjadi korban tindak pidana (berarti perlindungan HAM atau untuk kepentingan hukum seseorang);

b. Perlindungan untuk memperoleh jaminan/santunan hukum atas penderitaan/kerugian orang yang telah menjadi korban tindak pidana (identik dengan penyantunan korban). Bentuk santunan ini dapat berupa pemulihan nama baik (rehabilitasi), pemulihan keseimbangan batin (misalnya permaafan), pemberian ganti rugi (restitusi, kompensasi, jaminan/santunan kesejahteraan sosial), dan sebagainya.

Dari dua makna perlindungan korban, maka pada dasarnya ada dua sifat perlindungan yang dapat diberikan secara langsung oleh hukum, yakni bersifat preventif berupa perlindungan hukum untuk tidak menjadi korban tindak pidana dan represif berupa perlindungan untuk memperoleh jaminan/santunan hukum atas penderitaan/kerugian orang yang telah menjadi korban tindak pidana. Perlindungan yang bersifat preventif dan represif memegang peranan yang sama pentingnya dalam memberikan perlindungan terhadap masyarakat mengingat masyarakat yang telah menjadi korban tidak boleh begitu saja dibiarkan menderita tanpa ada upaya perlindungan apa pun dari negara.

12 Barda Nawawi Arief, Masalah Penegakkan Hukum dan Kebijakan Hukum Pidana dalam Penanggulangan Kejahatan, Jakarta: Kencana Prenada Media Group, 2007, hlm. 61. 
Dasar dari perlindungan korban kejahatan dapat dilihat dari beberapa teori, $\operatorname{adalah}^{13}$ :

a. Teori utilitas

Teori ini menitikberatkan pada kemanfaatan yang terbesar bagi jumlah yang terbesar. Konsep pemberian perlindungan pada korban kejahatan dapat diterapkan sepanjang memberikan kemanfaatan yang lebih besar dibandingkan dengan tidak diterapkannya konsep tersebut, tidak saja bagi korban kejahatan, tetapi juga bagi sistem penegakkan hukum pidana secara keseluruhan.

b. Teori tanggung jawab

Pada hakikatnya subjek hukum (orang maupun kelompok) bertanggungjawab terhadap segala perbuatan hukum yang dilakukannya sehingga apabila seseorang melakukan suatu tindak pidana yang mengakibatkan orang lain menderita kerugian (dalam arti luas), orang tersebut harus bertanggungjawab atas kerugian yang ditimbulkannya, kecuali ada alasan yang membebaskannya.

c. Teori ganti rugi

Sebagai perwujudan tanggung jawab karena kesalahannya terhadap orang lain, pelaku tindak pidana dibebani kewajiban untuk memberikan ganti kerugian pada korban atau ahli warisnya.

Konsep perlindungan terhadap korban secara teoritis dapat dilakukan dengan cara non-yuridis dan yuridis dalam bentuk tindakan-tindakan pencegahan. Perlindungan terhadap korban kejahatan diberikan tergantung pada jenis penderitaan/kerugian yang diderita oleh korban. Hak dan kewajiban korban yang seharusnya melekat pada korban adalah sebagai berikut ${ }^{14}$ :

a. Hak korban

1) Berhak mendapatkan kompensasi atas penderitaannya, sesuai dengan taraf keterlibatan korban itu sendiri dalam terjadinya kejahatan tersebut;

2) Berhak menolak, kompensasi untuk kepentingan pembuat korban karena tidak memerlukannya;

Ibid, hlm. 162-163

14 Arif Gosita, Masalah Korban Kecelakaan, Kumpulan Karangan, Jakarta: Akademika Presindo, 1983, hlm. 52-53. 
3) Berhak mendapat kompensasi untuk ahli warisnya bila korban meninggal dunia karena tindakan tersebut;

4) Berhak mendapat pembinaan dan rehabilitasi;

5) Berhak mendapat kembali hak miliknya;

6) Berhak menolak menjadi saksi bila hal itu akan membahayakan dirinya;

7) Berhak mendapat perlindungan dari ancaman pihak pembuat korban bila melapor atau menjadi saksi;

8) Berhak mendapat bantuan penasihat hukum; dan

9) Berhak mempergunakan upaya hukum (rechtmiddelen).

b. Kewajiban korban

1) Tidak sendiri membuat korban dengan mengadakan pembalasan (main hakim sendiri);

2) Berpartisipasi dengan masyarakat mencegah pembuatan korban lebih banyak lagi;

3) Mencegah kehancuran si pembuat korban baik oleh diri sendiri maupun oleh orang lain;

4) Ikut serta membina pembuat korban;

5) Bersedia dibina atau membina diri sendiri untuk tidak menjadi korban lagi;

6) Tidak menuntut restitusi yang tidak sesuai dengan kemampuan pembuat korban;

7) Memberikan kesempatan kepada pembuat korban untuk membayarkan restitusi pada pihak korban sesuai dengan kemampuannya (mencicil bertahap/imbalan jasa); dan

8) Menjadi saksi bila tidak membahayakan diri sendiri dan ada jaminan.

Uraian hak dan kewajiban korban ini sangat bermanfaat untuk informasi dan kepentingan praktis bagi korban atau keluarga korban, pembuat kejahatan serta anggota masyarakat lainnya. Peranan korban akan menentukan hak untuk memperoleh jumlah restitusi, tergantung pada tingkat peranannya terhadap terjadinya tindak pidana yang bersangkutan dan demikian juga dalam proses peradilan pidana.

Menjadi kewajiban pemerintah untuk memberikan perlindungan kepada korban yang diimplementasikan dalam peraturan perundang-undangan sebagai produk hukum yang berpihak kepada korban. 


\section{KESIMPULAN}

1. Pertanggungjawaban pidana, seorang apoteker harus jelas terlebih dahulu dinyatakan sebagai pembuat suatu tindak pidana (malapraktik). Pertanggungjawaban pidana kepada apoteker itu diminta atau tidak, adalah persoalan kedua, tergantung kebijakan pihak yang berkepentingan untuk memutuskan apakah dirasa perlu atau tidak untuk menuntut pertanggungjawaban pidana tersebut. Seorang apoteker dianggap mampu bertanggung jawab apabila apoteker tersebut menyadari akan tindakan yang sebenarnya dilakukannya dan akibat dari hasil perbuatannya tersebut. Suatu perbuatan dapat dikategorikan sebagai pharmacists malpractice apabila memenuhi rumusan delik pidana, yaitu perbuatan tersebut harus merupakan perbuatan tercela dan dilakukan sikap batin yang salah yaitu berupa kecerobohan atau kealpaan/kelalaian.

2. Perlindungan hukum terhadap korban malapraktik apoteker secara teoritis dapat dilakukan dengan cara non-yuridis dan yuridis dalam bentuk tindakantindakan pencegahan. Perlindungan terhadap korban kejahatan diberikan tergantung pada jenis penderitaan/kerugian yang diderita oleh korban. Dasar dari perlindungan korban kejahatan dapat dilihat dari beberapa teori, seperti teori utilitas, teori tanggung jawab dan teori ganti rugi.

\section{Daftar Pustaka}

\section{Buku}

Amir, Amri, Bunga Ranpai Hukum Kesehatan, Jakarta: Widya Medika, 1997.

Arief, Barda Nawawi, Bunga Rampai Kebijakan Hukum Pidana, Jakarta: Kencana, 2008.

Arief, Barda Nawawi, Masalah Penegakkan Hukum dan Kebijakan Hukum Pidana dalam

Penanggulangan Kejahatan, Jakarta: Kencana Prenada Media Group, 2007.

Gosita, Arif, Masalah Korban Kecelakaan, Kumpulan Karangan, Jakarta: Akademika Presindo, 1983.

Hadjon, Philipus M., Perlindungan Bagi Rakyat di Indonesia, Surabaya: PT. Bina Ilmu,1987. Hardjosaputra, Purwanto, Daftar Obat Indonesia Edisi II, Jakarta: PT. Mulia Purna Jaya Terbit, 2008.

Mansur, Dikdik M. Arief, Elisatris Gultom, Urgensi Perlindungan Korban Kejahatan Antara Norma dan Realita, Jakarta: PT Raja Grafindo Persada, 2007. 
Nasution, Bahder, Sistem Hukum, Jakarta: PT. Rineka Cipta, 2005.

Saleh, Roeslan, Perbuatan Pidana dan Pertanggungjawaban Pidana, Dua Pengertian Dasar dalam Hukum Pidana, Jakarta: Centra, 1998.

Saleh, Roeslan, Pikiran-Pikiran Tentang Pertanggung Jawaban Pidana, Cetakan Pertama, Jakarta: Ghalia Indonesia, 1982

Setiono, Rule of Law (Supremasi Hukum), Surakarta; Magister Ilmu Hukum Program Pascasarjana Universitas Sebelas Maret, 2004.

\section{Jurnal}

Haris, Oheo K., Telaah Yuridis Penerapan Sanksi Di Bawah Minimum Khusus Pada Perkara Pidana Khusus, Jurnal Ius Constituendum, Volume 2 Nomor 2 Tahun 2017, http://journals.usm.ac.id/index.php/jic/article/view/663 diakses pada tanggal 28 Juni 2019.

\section{Peraturan Perundang-undangan}

Undang-Undang Nomor 36 Tahun 2009 Tentang Kesehatan (Tambahan Lembaran Negara Republik Indonesia Nomor 50635).

Undang-Undang Nomor 36 Tahun 2014 Tentang Tenaga Kesehatan (Tambahan Lembaran Negara Republik Indonesia Nomor 5607). 